\section{Performance of Mechanical Thinners for Bloom or Green Fruit Thinning in Peaches}

\author{
Stephen S. Miller ${ }^{1,2}$ \\ U.S. Department of Agriculture, Agricultural Research Service, Appalachian \\ Fruit Research Station, 2217 Wiltshire Road, Kearneysville, WV 25430
}

James R. Schupp

Pennsylvania State University, Department of Horticulture, Fruit Research and Extension Center, 290 University Drive, Biglerville, PA 17307

Tara A. Baugher

Pennsylvania State University, 670 Old Harrisburg Road, Gettysburg, PA 17325

\section{Scott D. Wolford}

U.S. Department of Agriculture, Agricultural Research Service, Appalachian Fruit Research Station, 2217 Wiltshire Road, Kearneysville, WV 25430

Additional index words. Prunus persica, stone fruit, crop load management, fruit size, labor

Abstract. Peach (Prunus persica L. Batsch) thinning is a costly and time-consuming but necessary practice to produce a crop of marketable size fruit. A number of mechanical devices and methods have been developed and evaluated to reduce the cost and time required for hand thinning peach. This report provides additional evidence that a Darwin string thinner can effectively thin peach at bloom and a spiked drum shaker can thin at bloom or at the green fruit (pit hardening) stage. Five trials were conducted over 2 years in grower orchards with trees trained to a perpendicular $V$ system. A Darwin string thinner at $60 \%$ to $80 \%$ full bloom (FB) reduced crop load (fruit $/ \mathrm{cm}^{2} \mathrm{limb}$ cross-sectional area) on scaffold limbs by $21 \%$ to $50 \%$ compared with a hand-thinned control. At the $60 \%$ FB stage, a USDA-designed double-spiked drum shaker reduced crop load by $27 \%$ and in another trial, a USDA prototype single-drum shaker reduced crop load by $9 \%$. Across all trials, the spiked drum shakers (single or double units) removed an average of $37 \%$ of the green fruit. All mechanical devices reduced the time required for follow-up hand thinning. Follow-up hand-thinning costs (US\$/ha) were reduced an average of $27 \%$ by mechanical thinning devices over hand-thinned control trees. Fruit size was increased over handthinned controls by mechanical thinning in most, but not all, trials. A combined treatment of the Darwin string thinner at bloom followed by a drum shaker (single or double unit) at the green fruit stage produced the greatest net economic impact in a number of the trials. Despite overthinning in some trials, the mechanical thinning devices described provide a potential alternative to hand thinning alone in peach production.

It is well established that peach (Prunus persica L. Batsch) requires some form of thinning early in the growing season to produce a crop of marketable size fruit (Byers et al., 2003; Havis, 1962; Tukey and Einset, 1938). Early studies by Tukey and Einset (1938) and later by Havis (1962) demonstrated

\footnotetext{
Received for publication 19 Aug. 2010. Accepted for publication 15 Nov. 2010.

We thank Katie Hess-Reichard, Katy Lesser Clowney, Edwin Winzeler, and Katie Ellis, Penn State University, for their valuable assistance in these studies.

Mention of a trademark, proprietary product, or vendor does not constitute a guarantee or warranty of the product by the USDA and does not imply its approval to the exclusion of other products or vendors that also may be suitable.

${ }^{1}$ Research Horticulturist.

${ }^{2}$ To whom reprint requests should be addressed; e-mail stephen.miller@ars.usda.gov.
}

the benefit in peach fruit size with early (bloom or early Stage I) thinning. Despite a lack of supporting research, it is generally accepted that thinning also improves annual production compared with trees that receive no thinning (Byers, 1989; Tukey and Einset, 1938) and that the exact time of early thinning (bloom through early Stage I) has little or no effect on annual cropping (Tukey and Einset, 1938).

Chemical thinning, similar to that used in apple (Malus domestica Borkh.) production, has long been studied and attempted in peach but often with limited success. Hand fruit thinning is generally used to reduce crop load in peaches resulting in increased fruit size. Hand fruit thinning is one of the most laborintensive, costly practices for peach growers, often costing as much as U.S. \$2470/ha (U.S. $\$ 1000$ per acre) or more to hand thin freshmarket peaches (Warner, 2009).

Mechanical thinning could provide a reliable, economical alternative to the standard hand thinning or the more variable chemical thinning techniques used in peach production. Several mechanical methods for thinning peaches have been studied in the past (Baugher et al., 1991; Berlage and Langmo, 1982; Byers, 1990; Glenn et al., 1994; Powell et al., 1975). Powell et al. (1975) reported that yield and fruit size of peaches thinned with a whole tree mechanical shaker were similar to that obtained by conventional hand thinning methods in commercial orchard trials over a 6-year period. They reported that the mechanical tree shaker thinned trees without tree damage. Despite the apparent success with their whole-tree shaker, this method received very limited use among commercial fresh-market peach producers.

Thinning was achieved at bloom time with a rope curtain (Baugher et al., 1991), but multiple passes over the canopy were required and thinning in the lower canopy was generally poor. Berlage and Langmo (1982) reported that an inertia trunk shaker reduced the time required to thin peach trees but significantly reduced yield as a result of overthinning. Glenn et al. (1994) demonstrated that a mechanical spiked-drum shaker could effectively remove peaches on "Y" trained trees at the early green-fruit stage, but branch orientation affected the level of fruit removal. They reported that the drum shaker was "non-selective" and removed both large and small fruit. However, at ground speeds of either 0.5 or 2.0 $\mathrm{km} \cdot \mathrm{h}^{-1}$, the drum shaker significantly reduced the yield of large (greater than $7.6 \mathrm{~cm}$ ) diameter fruit suggesting it was in fact selective in removing larger sized fruit (Glenn et al., 1994).

Schupp et al. (2008) demonstrated that a mechanical string thinner could remove between $30 \%$ and $46 \%$ of the bloom on highdensity perpendicular $\mathrm{V}$ or quadrilateral-V trained peach trees and thus reduce crop load and the time required for follow-up hand thinning compared with hand thinning alone. Their results illustrated the importance of good tree training techniques because thinning on interior canopy limbs was quite variable. The string thinner originally tested was only adapted to bloom-thinning narrow vertical canopies. A prototype horizontal string blossom thinner and a hybrid that thinned in both vertical and horizontal positions demonstrated similar performance in open center-trained peach trees in commercial orchard trials conducted in 2008 and 2009 (Baugher et al., 2009, 2010). Blossom thinning is a concern for peaches grown in areas prone to late spring frosts.

Schupp et al. (2008) evaluated a direct drive double-spiked drum shaker developed by the USDA to harvest citrus for thinning peaches at the green fruit stage (20 to $30 \mathrm{~mm}$ diameter). In pillar growth habit peach trees, the drum shaker reduced crop load, increased fruit size, and reduced the follow-up handthinning time by $50 \%$ or more over handthinned control trees. Additional tests in commercial peach orchards with perpendicular-V or quadrilateral-V trained trees produced similar results (Schupp et al., 2008). However, Schupp et al. (2008) reported that the double drum shaker overthinned in most tests, removed the largest fruit at the time of 
thinning, and resulted in some bark damage to trees.

Rosa et al. (2008) designed and tested an electromagnetic limb shaker to mechanically thin green fruit on deciduous fruit trees. Although their prototype showed great promise in thinning several stone fruit species, the device alone resulted in overthinning in tree tops and would need additional automation design and integration to be an efficient/effective mechanical thinner.

Damerow and Blanke (2009) developed a novel thinning device with three horizontal rotating brushes that allowed more precise thinning in selected areas of apple tree canopies. The device is only adapted to bloom thinning and did produce leaf damage similar to hail damage in terms of torn leaves. The authors indicate the novel device has potential for bloom thinning stone fruit trees as well as apple.

The objective of the current study was to conduct additional tests with a Darwin (Darwin 300; Fruit-Tec, Deggenhausertal, Germany) mechanical string thinner at bloom, a Darwin string thinner at bloom plus the USDA double drum shaker at the green fruit stage, a grower-developed single-drum shaker at the green fruit stage, the USDA double-drum shaker at bloom, and a new USDA prototype single-drum shaker at bloom and/or at the green fruit stage.

\section{Materials and Methods}

All tests were conducted in commercial peach orchards near Biglerville, PA, in 2008 and 2009. All trees were mature bearing peach planted at $1.83 \mathrm{~m} \times 5.79 \mathrm{~m}(944$ trees/ha) and trained to a perpendicular-V system. In this system, each tree has two main scaffolds (or leaders), one oriented on each side of the tree and perpendicular to a line running down the center of the tree row (Fig. 1A). The trees in this study had narrow planar canopies $\approx 60$ to $75 \mathrm{~cm}$ in depth oriented on each side of the tree row. Canopy spread at the top of the V-shaped trees ranged from $2.7 \mathrm{~m}$ to $3.7 \mathrm{~m}$. Three peach cultivars were used in these trials: Sugar Giant, John Boy, and PF17. Canopy height measured from the ground varied among cultivars and within a test plot and ranged from $\approx 3.4 \mathrm{~m}$ to $\approx 5.0 \mathrm{~m}$. In general 'Sugar Giant' trees were the largest with most canopies between 4.5 and $5.0 \mathrm{~m}$ tall.

The Darwin mechanical string thinner for vertical canopies and the USDA direct-drive double-spiked drum shaker units used in the 2008 tests have been described (Schupp et al., 2008). The single-drum mechanical thinner used in 2008 was a grower-designed unit patterned after the double-drum unit designed by Peterson (1998) except one of the drum units was removed and replaced with a counterbalance weight. The single-drum unit was mounted on a tractor-drawn trailer and used the same method of operation as the USDA double-drum shaker.

For the 2009 tests, a smaller prototype spiked drum shaker was designed based on the original USDA double-drum shaker but with only a single spiked drum (Fig. 1). In addition, the trailer mount used in the original
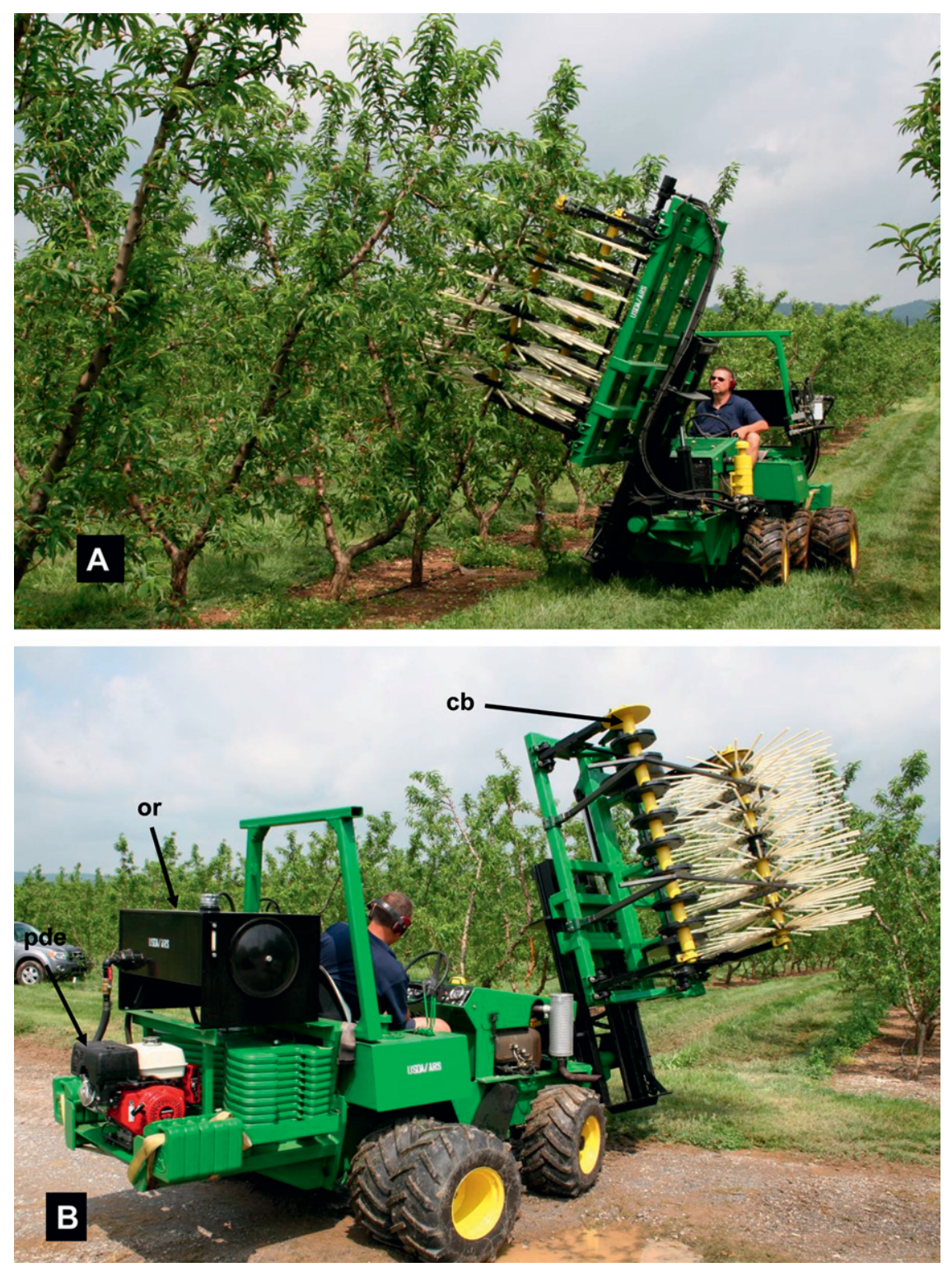

Fig. 1. USDA prototype single-spiked drum shaker for thinning peaches. (A) Thinning peach in a perpendicular- $\mathrm{V}$ trained peach planting at $\approx 35 \mathrm{~d}$ after full bloom; $(\mathbf{B})$ the USDA prototype singlespiked drum shaker mounted on a self-propelled chassis with auxiliary hydraulic pump, oil reservoir, and drive motor. Note the counterbalance (cb) spindle without nylon rods (spikes) and the auxiliary hydraulic oil reservoir (or) and pump drive engine (pde).

design was replaced with a self-propelled mobile chassis (Model 430 DitchWitch ${ }^{\circledR}$; Vermeer Manufacturing Co., Pella, IA) with the ditching and backhoe devices removed. The single spiked drum consisted of eight panels or whorls of 24 radially spaced $1.6-\mathrm{cm}$ diameter nylon rods $61 \mathrm{~cm}$ long bolted to plates on a central spindle. The drum measured $1.35 \mathrm{~m}$ in diameter and $1.2 \mathrm{~m}$ in height. A spindle of equal weight without rods was mounted adjacent to the spiked drum to provide a counterbalance. The single-drum shaker was mounted to a forklift mast on the front of the mobile chassis (Fig. 1A). The mast had a $1.2-\mathrm{m}$ vertical height adjustment and could be tilted $45^{\circ}$ back or $5^{\circ}$ forward from vertical to accommodate the plane of the tree's canopy. The eccentric movement of the drum produced a horizontal displacement at the rod tips of $\approx 8.9 \mathrm{~cm}$. An auxiliary hydraulic pump [1.89
$\left.\mathrm{L} \cdot \mathrm{s}^{-1}(30 \mathrm{gpm})\right]$ and oil reservoir were mounted on the rear of the mobile chassis to operate the drum shaker and the mast (Fig. 1B). A 13-hp gasoline-powered engine was used to operate the auxiliary hydraulic pump.

All tests with the Darwin string thinner were conducted at a tractor speed of $4.0 \mathrm{~km} \cdot \mathrm{h}^{-1}$. In general, the Darwin string thinner with a 3.0-m tall stringed thinning spindle made physical contact with approximately two-thirds of a tree's canopy height. The USDA doubledrum shaker and the grower single-drum shaker were also operated at a forward speed of $4.0 \mathrm{~km} \cdot \mathrm{h}^{-1}$. Preliminary tests with the USDA self-propelled single-drum prototype shaker suggested a slower travel speed was necessary to adjust for canopy position and to obtain reasonable fruit removal. The USDA single-drum prototype unit was operated at 1.2 or $1.8 \mathrm{~km} \cdot \mathrm{h}^{-1}$. The drum shaker units used 
in these trials were shorter in height than the Darwin string thinner and made physical contact with approximately one-third to one-half of a tree's total canopy height.

The experimental design in each trial was a randomized complete block with six blocks and six-tree plots. The desired forward travel speed of the tractor or self-propelled unit was set before engaging each test plot. Both the Darwin string thinner and the drum shakers (USDA or grower units) are hydraulically operated and were able to achieve the desired rotation speed or frequency within $2 \mathrm{sec}$ or less time when entering the test plot. Data were collected from the two center trees in each six-tree plot. The mechanical treatments in all trials were compared with hand thinning at 35 to $40 \mathrm{~d}$ after full bloom (DAFB). Flower density and crop load were determined on one pre-tagged scaffold limb on each of the test trees. Initial blossom density ranged from nine to 10 flowers $/ \mathrm{cm}^{2}$ limb cross-sectional area in 2008 and from three to 15 flowers $/ \mathrm{cm}^{2}$ limb cross-sectional area in 2009. Blossom removal with mechanical thinners was evaluated by counting all blossoms in the lower (1.5- to $2.5-\mathrm{m}$ height from the ground) and upper (2.5- to 4.0-m height) canopy regions on the tagged scaffold limb immediately before and after thinning. Scaffold limb circumference was recorded at the $1.5-\mathrm{m}$ and at the $2.5-\mathrm{m}$ height and used to compute flower or fruit densities for the two canopy areas. The total number of blossoms per scaffold limb was also recorded. At bloom and at 35 DAFB, "scaffold" is defined as a leader measured from $1.5 \mathrm{~m}$ above the ground to the top of the canopy. At harvest, "scaffold" represents the leader and associated canopy measured from the ground to the top of the canopy. Reduction in flower/fruit density was evaluated the day of thinning and again after physiological drop (35 to 40 DAFB) by calculating number of blossoms or fruit per limb cross-sectional area in the upper and lower canopies. Follow-up hand thinning was performed on all trees by commercial thinners hired by the grower cooperators. At each site, two experienced thinners were identified and selected by the crew leader to hand-thin the test plots. Thinners were instructed to thin test plots to achieve a commercial level of cropping based on total crop load for the scaffold. Thinners were cautioned against using fruit spacing as the sole basis for adjusting crop load. Each tree in the six-tree plot was thinned independently with one individual on one side of the canopy and the second individual thinning the other side of the canopy down the row. A stepladder was required to thin the tops of all trees. The time required to hand-thin was recorded on the two center data trees. The data trees were not identified to the hand thinners and additional instruction was not provided once the hand thinners began thinning the test plots.

At harvest, a sample of 40 to 50 firm-ripe fruit was collected from the center trees in each plot with equal numbers of fruit collected from the designated lower and upper canopy areas and combined for the total sample. The total fruit sample was evaluated for mean fruit diameter and fruit size distribution. Yields were calculated from fruit per scaffold counts and percent size distribution. 'John Boy' and 'Sugar Giant' treatment trees were examined soon after thinning for areas on the main scaffold where the bark had been broken and/or removed by the mechanical thinning devices. In addition, the number of 1year-old shoots or older branches broken during the thinning operation was recorded per tree. All data were subjected to an analysis of variance and treatments were separated using Fisher's protected least significant difference test.

Economic partial budget analyses (Harper et al., 2002) were performed to evaluate the potential impact of each thinning treatment on fruit returns. Mechanical thinning costs, based on capital costs of $\$ 13,280$ for the Darwin string thinner and $\$ 20,000$ for the USDA drum shaker, a 15-year useful life of equipment, and $8 \%$ interest rate averaged U.S. $\$ 67.85 /$ ha for the string thinner and U.S. $\$ 88.43$ for the drum shaker, including tractor cost $(\$ 12.00 / \mathrm{h})$ and labor $(\$ 12.00 / \mathrm{h})$. Realized economic savings were calculated from follow-up hand-thinning time, fruit size distribution, and average yield. Follow-up handthinning costs were based on a labor rate of $\$ 8.50 / \mathrm{h}$ in 2008 and $\$ 8.75 / \mathrm{h}$ in 2009 . Commercial prices for the various size categories for each cultivar and year were obtained from the USDA Agricultural Marketing Service Report, Appalachian Region (USDA, 2009).

\section{Results and Discussion}

Flower density, crop load, and fruit numbers. The Darwin string thinner alone effectively reduced flower density (flowers $/ \mathrm{cm}^{2}$ limb cross-sectional area) in the upper canopy of 'Sugar Giant' peach trees at 80\% FB in 2008 but had no effect on flower density in the lower canopy or on the scaffold limbs (Table 1). Similar results were obtained in 'John Boy' peach trees thinned at $60 \% \mathrm{FB}$ in 2008 and 2009. The USDA double-drum shaker operating at $3.6 \mathrm{~Hz}$ reduced flower density in the upper canopy and on scaffold limbs in 'John Boy' peaches in 2008. There was a slight, but non-significant, reduction in flower density in the upper canopy and on scaffold limbs in 'John Boy' peach trees with the USDA singledrum shaker at $60 \% \mathrm{FB}$ at $1.2 \mathrm{~km} \cdot \mathrm{h}^{-1}$ and 5.0 $\mathrm{Hz}$ in 2009 (Table 1).

Clearly the string thinner was effective in reducing flower density at both the $60 \%$ and $80 \%$ FB stage, which supports earlier findings (Baugher et al., 2009, 2010; Schupp et al., 2008). Results with the two USDA drum shakers at bloom time were not as conclusive. In 2008 the double-drum shaker effectively reduced flower density, but 1 year later in the same cultivar, the single-drum shaker was ineffective. With two sets of spiked rods, the double-drum shaker doubles the opportunity for fruit removal compared with the singledrum unit. Bloom thinning with a singledrum unit may require frequencies above $5.0 \mathrm{~Hz}$ to achieve bloom removal rates equal to the double-drum unit.
The effect of the Darwin string thinner or the drum shaker devices on peach crop load was variable depending on cultivar, year, timing, and treatment (mechanical device alone or in combination, drum shaker frequency, etc.) (Table 1). In 2008, all treatments in the 'Sugar Giant' trees reduced crop load (fruit $/ \mathrm{cm}^{2}$ cross-sectional area) in the upper and lower canopies and on scaffold limbs compared with control trees at 35 DAFB (data taken before follow-up hand thinning) (Table 1). The Darwin string thinner at $80 \% \mathrm{FB}$ or the USDA double-drum shaker at 35 DAFB produced similar crop loads in 'Sugar Giant' trees; combining these two treatments resulted in a numerical reduction in crop load, but the difference in crop load for the combined treatment was not significantly less than that for the either treatment alone (Table 1). As the cultivar name implies, Sugar Giant is a large-fruited peach. Given the crop load values for the mechanically thinned trees (average of 1.3 fruit $/ \mathrm{cm}^{2}$ limb cross-sectional area) and the fruit size at harvest, it would be reasonable to suggest that mechanical thinning in this trial probably resulted in overthinning the trees.

On 'John Boy' peaches in 2008, only one treatment, the Darwin string thinner at $60 \%$ FB, followed by the grower's single-drum shaker at 35 DAFB reduced crop load in the upper canopy below that on the control trees (Table 1). Crop load in the lower canopy did not differ among any of the treatments in 'John Boy' in 2008. Crop load on scaffold limbs of 'John Boy' peach in 2008 was reduced by a combination treatment of Darwin string thinner at $60 \% \mathrm{FB}$ followed by either the USDA double-drum shaker or the grower single-drum shaker at 35 DAFB. Crop load levels for the 'John Boy' in 2008, whereas not as low as for the treatments in 'Sugar Giant', are sufficiently low to suggest that some overthinning may have occurred.

Mechanical thinning treatments applied to 'John Boy' peaches in 2009 reduced crop load below that for the control trees in the upper canopy except for the USDA prototype single-drum shaker used at the $60 \%$ FB stage (Table 1). No treatment affected crop load in the lower canopy compared with the control trees. On scaffold limbs, only the combination of the USDA single-drum shaker at $60 \%$ $\mathrm{FB}$ and repeated at $35 \mathrm{DAFB}$ reduced crop load compared with the hand-thinned control. Failure to reduce crop load on 'John Boy' scaffold limbs in the string-thinned or the drum shaker treatments alone suggests the mechanical devices are primarily effective where the device makes physical contact with the canopy and much less effective outside this area. Although this would be expected for the string thinner, the energy released from the drum shaker should be transmitted to areas outside the physical area of contact and thus provide some thinning in portions of the canopy not directly contacted by the drum shaker rods. The trees in these trials did not form a perfectly flat planar canopy, which necessitated that the vertical tilt or angle of the thinning devices be adjusted to best 
Table 1. Peach blossom thinning and fruit set response to a vertical string thinner, drum shakers, or a combination of thinning treatments, 2008-2009.

\begin{tabular}{|c|c|c|c|c|c|c|c|c|c|}
\hline \multirow{2}{*}{$\begin{array}{l}\text { Thinning } \\
\text { treatment }^{z}\end{array}$} & \multirow{2}{*}{$\begin{array}{c}\text { Forward } \\
\text { speed }^{\mathrm{w}} \\
\left(\mathrm{km} \cdot \mathrm{h}^{-1}\right)\end{array}$} & \multirow{2}{*}{$\begin{array}{l}\text { Machine } \\
\text { speed }^{\mathrm{w}}\end{array}$} & \multirow{2}{*}{$\begin{array}{l}\text { Growth } \\
\text { stage }^{w}\end{array}$} & \multicolumn{3}{|c|}{$\begin{array}{l}\text { Flower density }{ }^{\mathrm{y}} \text { (flowers } / \mathrm{cm}^{2} \\
\text { limb-cross-sectional area) }\end{array}$} & \multicolumn{3}{|c|}{$\begin{array}{c}\text { Crop load (density) } 35 \text { DAFB }^{\mathrm{x}} \\
\text { (fruit } / \mathrm{cm}^{2} \text { limb-cross-sectional area) }\end{array}$} \\
\hline & & & & Upper canopy $^{\mathrm{V}}$ & Lower canopy $^{\mathrm{v}}$ & Scaffold $^{v}$ & Upper canopy & Lower canopy & $\overline{\text { Scaffold }}$ \\
\hline & & & & \multicolumn{6}{|c|}{ 'Sugar Giant', 2008} \\
\hline Darwin & 4.0 & $180 \mathrm{rpm}$ & $80 \% \mathrm{FB}^{\mathrm{u}}$ & $7.0 \mathrm{~b}^{\mathrm{t}}$ & $2.6 \mathrm{a}$ & $8.9 \mathrm{a}$ & $1.3 \mathrm{~b}$ & $0.5 \mathrm{~b}$ & $1.6 \mathrm{~b}$ \\
\hline USDA DD & 4.0 & $3.6 \mathrm{~Hz}$ & 35 DAFB & - & - & - & $1.3 \mathrm{~b}$ & $0.5 \mathrm{~b}$ & $1.5 \mathrm{~b}$ \\
\hline Darwin & 4.0 & $180 \mathrm{rpm}$ & $80 \% \mathrm{FB}$ & & & & & & \\
\hline + USDA DD & 4.0 & $3.6 \mathrm{~Hz}$ & 35 DAFB & - & - & - & $0.7 \mathrm{~b}$ & $0.2 \mathrm{~b}$ & $0.8 \mathrm{~b}$ \\
\hline Control & \multirow{2}{*}{\multicolumn{2}{|c|}{ Hand thinned }} & 35 DAFB & $9.4 \mathrm{a}$ & $2.9 \mathrm{a}$ & $10.7 \mathrm{a}$ & $2.6 \mathrm{a}$ & $1.1 \mathrm{a}$ & $3.2 \mathrm{a}$ \\
\hline & & & & \multicolumn{6}{|c|}{ 'John Boy', 2008} \\
\hline Darwin & 4.0 & $180 \mathrm{rpm}$ & $60 \% \mathrm{FB}$ & $6.5 \mathrm{~b}$ & $3.2 \mathrm{a}$ & $7.2 \mathrm{~b}$ & $3.0 \mathrm{ab}$ & $1.1 \mathrm{a}$ & $3.0 \mathrm{ab}$ \\
\hline USDA DD & 4.0 & $3.6 \mathrm{~Hz}$ & $60 \% \mathrm{FB}$ & $6.1 \mathrm{~b}$ & $3.1 \mathrm{a}$ & $6.7 \mathrm{~b}$ & $2.9 \mathrm{ab}$ & $1.4 \mathrm{a}$ & $3.0 \mathrm{ab}$ \\
\hline Grower SD & 4.0 & $3.6 \mathrm{~Hz}$ & 35 DAFB & - & - & - & $4.2 \mathrm{ab}$ & $1.4 \mathrm{a}$ & $3.6 \mathrm{ab}$ \\
\hline USDA DD & 4.0 & $3.6 \mathrm{~Hz}$ & 35 DAFB & - & - & - & $3.1 \mathrm{ab}$ & $1.0 \mathrm{a}$ & $3.0 \mathrm{ab}$ \\
\hline Darwin & 4.0 & $180 \mathrm{rpm}$ & $60 \% \mathrm{FB}$ & & & & & & \\
\hline + Grower SD & 4.0 & $3.6 \mathrm{HZ}$ & 35 DAFB & - & - & - & $2.4 \mathrm{~b}$ & $1.2 \mathrm{a}$ & $2.5 \mathrm{~b}$ \\
\hline Darwin & 4.0 & $180 \mathrm{rpm}$ & $60 \% \mathrm{FB}$ & & & & & & \\
\hline + USDA DD & 4.0 & $3.6 \mathrm{~Hz}$ & 35 DAFB & - & - & - & $3.2 \mathrm{ab}$ & $1.3 \mathrm{a}$ & $2.8 \mathrm{~b}$ \\
\hline Control & \multicolumn{2}{|c|}{ Hand thinned } & 35 DAFB & $10.4 \mathrm{a}$ & $4.0 \mathrm{a}$ & $9.9 \mathrm{a}$ & $4.4 \mathrm{a}$ & $1.5 \mathrm{a}$ & $4.1 \mathrm{a}$ \\
\hline \multicolumn{10}{|c|}{ 'John Boy', 2009} \\
\hline Darwin & 4.0 & $150 \mathrm{rpm}$ & $60 \% \mathrm{FB}$ & $9.1 \mathrm{~b}$ & $5.2 \mathrm{a}$ & $11.2 \mathrm{~b}$ & $5.9 \mathrm{~b}$ & $3.0 \mathrm{a}$ & $7.0 \mathrm{ab}$ \\
\hline USDA SD & 1.2 & $5.0 \mathrm{~Hz}$ & $60 \% \mathrm{FB}$ & $12.5 \mathrm{ab}$ & $5.5 \mathrm{a}$ & $12.7 \mathrm{ab}$ & $9.5 \mathrm{a}$ & $3.2 \mathrm{a}$ & $8.8 \mathrm{a}$ \\
\hline USDA SD & 1.2 & $5.0 \mathrm{~Hz}$ & 35 DAFB & - & - & - & $5.7 \mathrm{~b}$ & $3.3 \mathrm{a}$ & $7.0 \mathrm{ab}$ \\
\hline USDA SD & 1.2 & $5.0 \mathrm{~Hz}$ & $60 \% \mathrm{FB}$ & & & & & & \\
\hline + USDA SD & 1.2 & $5.0 \mathrm{~Hz}$ & 35 DAFB & - & - & - & $4.8 \mathrm{~b}$ & $2.3 \mathrm{a}$ & $5.4 \mathrm{~b}$ \\
\hline Control & \multicolumn{2}{|c|}{ Hand thinned } & 35 DAFB & $15.6 \mathrm{a}$ & $5.5 \mathrm{a}$ & $14.8 \mathrm{a}$ & $10.0 \mathrm{a}$ & $3.0 \mathrm{a}$ & $8.9 \mathrm{a}$ \\
\hline & & & & \multicolumn{6}{|c|}{ 'PF17', Trial 1, 2009} \\
\hline USDA SD & 1.2 & $4.2 \mathrm{~Hz}$ & 35 DAFB & - & - & - & $5.0 \mathrm{a}$ & $1.8 \mathrm{ab}$ & $5.8 \mathrm{a}$ \\
\hline USDA SD & 1.2 & $5.0 \mathrm{~Hz}$ & 35 DAFB & - & - & - & $4.0 \mathrm{a}$ & $1.6 \mathrm{ab}$ & $4.6 \mathrm{ab}$ \\
\hline USDA SD & 1.2 & $5.8 \mathrm{~Hz}$ & 35 DAFB & - & - & - & $4.0 \mathrm{a}$ & $1.1 \mathrm{~b}$ & $3.9 \mathrm{~b}$ \\
\hline USDA SD & 1.8 & $4.2 \mathrm{~Hz}$ & 35 DAFB & - & - & - & $5.2 \mathrm{a}$ & $2.2 \mathrm{a}$ & $5.8 \mathrm{a}$ \\
\hline Control & \multicolumn{2}{|c|}{ Hand thinned } & 35 DAFB & - & - & - & $5.5 \mathrm{a}$ & $1.4 \mathrm{~b}$ & $5.8 \mathrm{a}$ \\
\hline & & & & \multicolumn{6}{|c|}{ 'PF17', Trial 2, 2009} \\
\hline USDA SD & 1.2 & $5.0 \mathrm{~Hz}$ & $60 \% \mathrm{FB}$ & - & - & - & $3.5 \mathrm{a}$ & $1.4 \mathrm{a}$ & $4.0 \mathrm{a}$ \\
\hline USDA SD & 1.2 & $5.0 \mathrm{~Hz}$ & 35 DAFB & - & - & - & $1.1 \mathrm{~b}$ & $0.6 \mathrm{~b}$ & $1.4 \mathrm{~b}$ \\
\hline USDASD & 1.2 & $5.0 \mathrm{~Hz}$ & $60 \% \mathrm{FB}$ & & & & & & \\
\hline + USDA SD & 1.2 & $5.0 \mathrm{~Hz}$ & 35 DAFB & - & - & - & $0.9 \mathrm{~b}$ & $0.5 \mathrm{~b}$ & $1.2 \mathrm{~b}$ \\
\hline Control & \multicolumn{2}{|c|}{ Hand thinned } & 35 DAFB & - & - & - & $4.4 \mathrm{a}$ & $1.2 \mathrm{a}$ & $4.4 \mathrm{a}$ \\
\hline
\end{tabular}

${ }^{2}$ Darwin is the Darwin 300 string thinner (Fruit-Tec, Deggenhausertal, Germany); USDA DD is the USDA double-spiked drum shaker that is a trailer-mounted unit designed to harvest citrus; Grower SD is a trailer-mounted grower-built single-drum unit patterned after the USDA DD unit but with one drum; USDA SD is a self-propelled prototype single-drum unit designed and built by the USDA. All trees trained to a perpendicular-V system with one main scaffold oriented on each side of the tree and perpendicular to a line running down the center of the tree row.

${ }^{y}$ After mechanical thinning treatment but before the hand-thinning control treatment.

${ }^{\mathrm{x}} \mathrm{DAFB}=$ days after full bloom; before follow-up hand thinning.

${ }^{\text {w}}$ Forward speed is travel speed of the tractor or the self-propelled unit. Machine speed is the operating speed of the thinning machine in revolutions or Hertz. Growth stage is the stage of tree development or time in days after full bloom when treatment was applied.

vUpper canopy is the canopy area on one leader at a distance of 2.5 to $4.0 \mathrm{~m}$ above the ground; lower canopy is the area from 1.5 to $2.5 \mathrm{~m}$ above the ground; and scaffold is the canopy on one of the two leaders of the perpendicular- $\mathrm{V}$ trained trees measured from $1.5 \mathrm{~m}$ above the ground to the top of the canopy.

${ }^{u} \mathrm{FB}=$ full bloom.

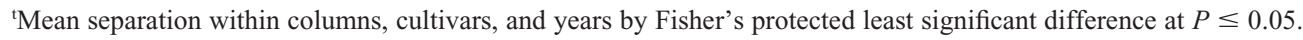

interact with the individual tree canopies. This was a problem for all of the mechanical thinning devices but was particularly challenging for the string thinner in a few instances that resulted in less than ideal contact with the lower canopy. The need for rapid adjustment of the mechanical thinner by the machine operator may have accounted for the lack of thinning observed in some treatments in the lower canopy region.

Two separate trials using 'PF 17' peach trees were conducted in 2009 with the USDA single-drum prototype shaker (Table 1). In the first trial, two travel speeds $\left(1.2\right.$ or $\left.1.8 \mathrm{~km} \cdot \mathrm{h}^{-1}\right)$ were evaluated at various shaker head frequencies $(4.2,5.0$, or $5.8 \mathrm{~Hz})$. In the second trial, travel speed and shaker frequency were held constant and the shaker was applied at $60 \% \mathrm{FB}, 35 \mathrm{DAFB}$, or a combination of both treatments. Increasing shaker frequency or increasing travel speed at the lower shaker frequency had no effect on crop load in the upper canopy compared with the control trees. When the USDA single-drum shaker was driven at $1.2 \mathrm{~km} \cdot \mathrm{h}^{-1}$ and operated at $5.8 \mathrm{~Hz}$, crop load on the tagged scaffold limb was reduced, but at higher travel speeds or lower frequencies, the single-drum shaker was ineffective at reducing crop load on the tagged scaffold limbs. When the USDA single-drum shaker was operated at a set travel speed $\left(1.2 \mathrm{~km} \cdot \mathrm{h}^{-1}\right)$ and frequency $(5.0 \mathrm{~Hz})$, the single-drum shaker at $60 \% \mathrm{FB}$ was ineffective in reducing crop load in any portion of the canopy measured (Table 1 ), but at 35 DAFB (green fruit stage) alone or at $60 \%$ FB plus repeated at $35 \mathrm{DAFB}$, the single-drum shaker significantly reduced crop load in the upper and lower canopies and on tagged scaffold limbs in the 'PF17' peach trees. Failure to reduce crop load by the USDA single-drum shaker at FB is probably explained by the light weight of the blossoms relative to that of developing green fruits. Because shakers thin by creating directional momentum, the force required to remove fruits might be expected to be more easily attained compared with flowers because of their greater mass. Although this removal mechanism is not optimal for thinning blossoms, our previous studies (Schupp et al., 2008) demonstrate that blossom thinning is highly effective for increasing peach fruit size, and a grower who invested in this technology could conceivably use it at either timing or both to obtain the desired results.

As reported in previous papers (Baugher et al., 2009, 2010; Schupp et al., 2008), flower density and crop load (fruit $/ \mathrm{cm}^{2} \mathrm{limb}$ cross-sectional area) were lower in the lower canopy of trees in this study than in the upper canopy (Table 1). This appears to be a common condition in peach canopies probably the result of shading leading to fewer and poorer quality bearing shoots in the lower portion of the tree (Marini and Sowers, 1990). In addition, by design, our lower canopy 
included a $1.0-\mathrm{m}$ section from $1.5 \mathrm{~m}$ to $2.5 \mathrm{~m}$ above the ground, whereas the upper canopy was comprised of a greater canopy area $(2.5 \mathrm{~m}$ to $4.0 \mathrm{~m}$ above the ground). Flower and fruit densities for lower and upper canopies were computed from scaffold limb measurements taken at the starting point for these respective areas. This may have influenced the flower/ fruit density to reflect a lower number.

The Darwin string thinner and/or the drum shaker units (USDA or grower single or USDA double) produced comparable crop loads in a number of the trials at 35 DAFB. When a bloom thinner treatment was combined with one of the green fruit stage thinning treatments, there was often an additional reduction in crop load, but the differences were not significant as in the case of 'Sugar Giant' in 2008 or 'PF17' Trial 2 in 2009. Previous tests (Schupp et al., 2008) in some cultivars resulted in significant reductions in crop load with the USDA doubledrum shaker at the green fruit stage compared with the Darwin string thinner at bloom.

Crop loads on hand-thinned and mechanically thinned trees in this study and in a previously published report (Schupp et al., 2008) were generally approximately five fruit $/ \mathrm{cm}^{2}$ limb or trunk cross-sectional area or below. Observations (S. Miller, unpublished data) and reports (Miller and Tworkoski, 2010) indicate that crop load densities below five fruit $/ \mathrm{cm}^{2}$ in peach are associated with the larger size $(\approx 7.6 \mathrm{~cm})$ fruits preferred by consumers.

Fruit counts taken after bloom thinning but before mechanical drum shaker thinning were generally reflective of the treatment (Table 2). In all trials over the 2-year period, the Darwin string thinning at bloom reduced the fruit count numbers below that for the hand-thinned control trees. The USDA dou- ble-drum shaker at the $60 \%$ FB bloom stage reduced fruit counts in 'John Boy' in 2008, but the single-drum unit was not effective in reducing the fruit count in 'John Boy' in 2009. However, the USDA single-drum unit was effective in reducing fruit count numbers in the 'PF17' Trial 2 study in 2009 when operated at the same speed and frequency as in the earlier 'John Boy' trial (Table 2). The USDA double-drum shaker removed an average of $37 \%$ of the fruit at the green fruit stage when compared among four treatments in 2008. In 2009 among eight individual treatments, the USDA single-drum shaker also removed an average of $37 \%$ of the fruit. However, in the case of the single-drum shaker, the range among the treatments was greater than for the double-drum shaker $(\approx 21 \%$ to $62 \%$ of the fruit for the single-drum shaker versus $\approx 30 \%$ to $45 \%$ range for the double-drum unit).

Table 2. The number of peach fruit at $35 \mathrm{~d}$ after full bloom (DAFB), the fruit removed by mechanical drum shakers, and the fruit count at harvest as affected by a vertical string thinner, drum shakers, or a combination of thinning treatments in 2008-2009. ${ }^{\mathrm{z}}$

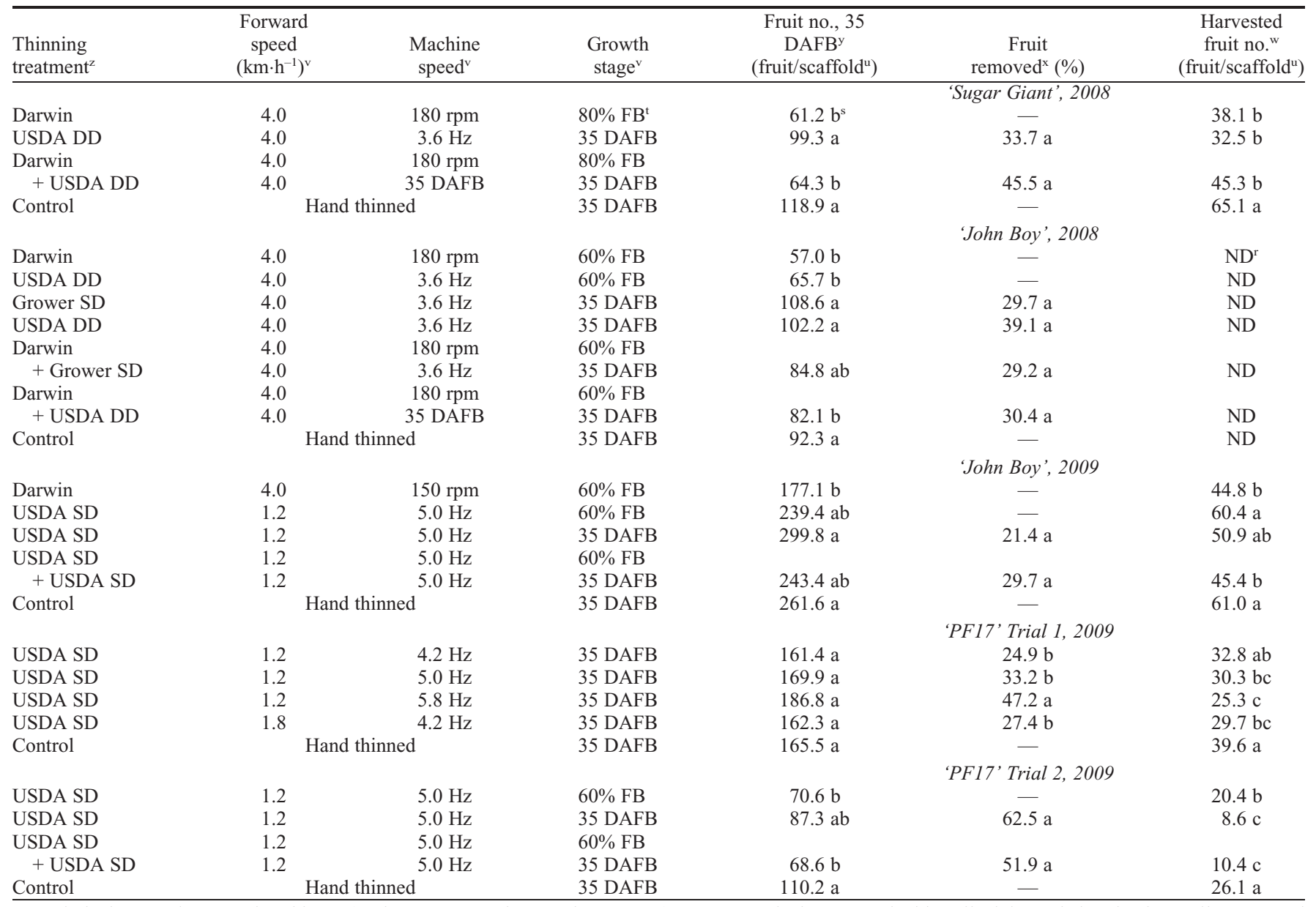

${ }^{2}$ Darwin is the Darwin 300 string thinner (Fruit-Tec, Deggenhausertal, Germany); USDA DD is the USDA double-spiked drum shaker that is a trailer-mounted unit designed to harvest citrus; Grower SD is a trailer-mounted grower-built single-drum unit patterned after the USDA DD unit but with one drum; USDA SD is a self-propelled prototype single-drum unit designed and built by the USDA. All trees trained to a perpendicular-V system with one main scaffold oriented on each side of the tree and perpendicular to a line running down the center of the tree row.

${ }^{y}$ Number of fruit on the scaffold at 35 DAFB and before green fruit thinning (mechanical or hand) but after mechanical bloom thinning treatment.

xPercent of green fruit removed by mechanical drum shaker treatment; before follow-up hand thinning.

${ }^{\mathrm{v} F o r w a r d ~ s p e e d ~ i s ~ t r a v e l ~ s p e e d ~ o f ~ t h e ~ t r a c t o r ~ o r ~ t h e ~ s e l f-p r o p e l l e d ~ u n i t . ~ M a c h i n e ~ s p e e d ~ i s ~ t h e ~ o p e r a t i n g ~ s p e e d ~ o f ~ t h e ~ t h i n n i n g ~ m a c h i n e ~ i n ~ r e v o l u t i o n s ~ o r ~ H e r t z . ~}$ Growth stage is the stage of tree development or time in days after full bloom when treatment was applied.

uScaffold is the scaffold limb of one of the two leaders of the perpendicular-V trained trees. At 35 DAFB, the scaffold measurement was taken from $1.5 \mathrm{~m}$ above the ground to the top of the canopy and at harvest the scaffold was measured from the ground to the top of the canopy.

${ }^{\mathrm{t}} \mathrm{FB}=$ full bloom.

'Mean separation within columns, cultivars, and years by Fisher's protected least significant difference at $P \leq 0.05$.

${ }^{\mathrm{r}} \mathrm{ND}=$ no data taken 
This may be chance, but operator experience and/or canopy architecture may also play a role in this variability. In addition, the double-drum shaker has two sets of rods increasing the opportunity for fruit to be detached.

Harvested fruit numbers from tagged scaffold limbs were generally reduced by mechanical thinning treatments compared with the hand-thinned controls (Table 2). The only exceptions occurred with the USDA single-drum shaker at $60 \%$ FB ('John Boy', 2009) or at 35 DAFB ('John Boy', 2009 and 'PF17', Trial 1, $4.2 \mathrm{~Hz}$ ). Producers indicated that "ideal" fruit numbers per scaffold in these trials would be 30 fruit for the 'PF17' trees and 40 fruit for the 'Sugar Giant' and 'John Boy' 2009 trees (Chris Baugher and Joy Cline, respectively; personal communication). Based on the suggested cropping levels, mechanically thinned 'John Boy' and 'PF17' trees in 2009 and 'Sugar

Giant' in 2008 would be characterized as approaching the grower's defined "ideal" levels.

Follow-up hand thinning time. The Darwin string thinner reduced follow-up handthinning time in 2008 at $80 \%$ FB in 'Sugar Giant' but not in 'John Boy' at 60\% FB (Table 3). The initial performance (Schupp et al., 2008) of the Darwin ${ }^{\mathrm{TM}} 300$ string thinner demonstrated a consistent reduction in followup hand-thinning time at the $20 \%$ or $80 \%$ FB stage. More recent studies (Baugher et al., 2009) with a prototype horizontal string thinner reported no significant reduction in follow-up hand-thinning time in some trials at travel speeds of $4.0 \mathrm{~km} \cdot \mathrm{h}^{-1}$ at the $60 \% \mathrm{FB}$ stage.

The grower single-drum shaker and the USDA double-drum shaker reduced followup thinning time in all tests in 2008 except when the USDA double drum was used to thin green fruit in the 'Sugar Giant' trees. Com-

Table 3. Follow-up hand-thinning time for several peach cultivars after mechanically thinning with a vertical string thinner, drum shakers, or a combination of treatments, 2008-2009.

\begin{tabular}{|c|c|c|c|c|}
\hline $\begin{array}{l}\text { Thinning } \\
\text { treatment }^{\mathrm{y}}\end{array}$ & $\begin{array}{c}\text { Forward } \\
\text { speed } \\
\left(\mathrm{km} \cdot \mathrm{h}^{-1}\right)^{\mathrm{x}}\end{array}$ & $\begin{array}{c}\text { Machine } \\
\text { speed }^{\mathrm{x}}\end{array}$ & $\begin{array}{l}\text { Growth } \\
\text { stage }^{\mathrm{x}}\end{array}$ & $\begin{array}{l}\text { Hand thinning } \\
\text { at } 35 \text { to } 40 \\
\text { DAFB }^{\mathrm{z}}\left(\mathrm{h} \cdot \mathrm{ha}^{-1}\right)\end{array}$ \\
\hline & & & \multicolumn{2}{|c|}{ 'Sugar Giant', 2008} \\
\hline Darwin & 4.0 & $180 \mathrm{rpm}$ & $80 \% \mathrm{FB}^{\mathrm{w}}$ & $56.8 \mathrm{bc}^{\mathrm{v}}$ \\
\hline USDA DD & 4.0 & $3.6 \mathrm{~Hz}$ & 35 DAFB & $86.7 \mathrm{ab}$ \\
\hline Darwin & 4.0 & $180 \mathrm{rpm}$ & $80 \%$ FB & \\
\hline + USDA DD & 4.0 & $3.6 \mathrm{~Hz}$ & 35 DAFB & $52.6 \mathrm{c}$ \\
\hline Control & \multicolumn{2}{|c|}{ Hand thinned } & 35 DAFB & $93.6 \mathrm{a}$ \\
\hline & & & \multicolumn{2}{|c|}{ 'John Boy', 2008} \\
\hline Darwin & 4.0 & $180 \mathrm{rpm}$ & $60 \% \mathrm{FB}$ & $55.1 \mathrm{ab}$ \\
\hline USDA DD & 4.0 & $3.6 \mathrm{~Hz}$ & $60 \% \mathrm{FB}$ & $52.1 \mathrm{bc}$ \\
\hline Grower SD & 4.0 & $3.6 \mathrm{~Hz}$ & 35 DAFB & $52.6 \mathrm{bc}$ \\
\hline USDA DD & 4.0 & $3.6 \mathrm{~Hz}$ & 35 DAFB & $49.6 \mathrm{bc}$ \\
\hline Darwin & 4.0 & $180 \mathrm{rpm}$ & $60 \% \mathrm{FB}$ & \\
\hline + Grower SD & 4.0 & $3.6 \mathrm{~Hz}$ & 35 DAFB & $45.4 \mathrm{bc}$ \\
\hline Darwin & 4.0 & $180 \mathrm{rpm}$ & $60 \% \mathrm{FB}$ & \\
\hline + USDA DD & 4.0 & $3.6 \mathrm{~Hz}$ & 35 DAFB & $39.5 \mathrm{c}$ \\
\hline Control & \multicolumn{2}{|c|}{ Hand thinned } & 35 DAFB & $68.9 \mathrm{a}$ \\
\hline & & & \multicolumn{2}{|c|}{ 'John Boy', 2009} \\
\hline Darwin & 4.0 & $150 \mathrm{rpm}$ & $60 \% \mathrm{FB}$ & $44.8 \mathrm{~b}$ \\
\hline USDA SD & 1.2 & $5.0 \mathrm{~Hz}$ & $60 \% \mathrm{FB}$ & $54.4 \mathrm{ab}$ \\
\hline USDA SD & 1.2 & $5.0 \mathrm{~Hz}$ & 35 DAFB & $49.6 \mathrm{~b}$ \\
\hline USDA SD & 1.2 & $5.0 \mathrm{~Hz}$ & $60 \% \mathrm{FB}$ & \\
\hline + USDA SD & 1.2 & $5.0 \mathrm{~Hz}$ & 35 DAFB & $49.5 \mathrm{~b}$ \\
\hline Control & \multicolumn{2}{|c|}{ Hand thinned } & 35 DAFB & $67.5 \mathrm{a}$ \\
\hline & & & \multicolumn{2}{|c|}{ 'PF17’ Trial 1, 2009} \\
\hline USDA SD & 1.2 & $4.2 \mathrm{~Hz}$ & 35 DAFB & $65.2 \mathrm{~b}$ \\
\hline USDA SD & 1.2 & $5.0 \mathrm{~Hz}$ & 35 DAFB & $64.4 \mathrm{~b}$ \\
\hline USDA SD & 1.2 & $5.8 \mathrm{~Hz}$ & 35 DAFB & $64.5 \mathrm{~b}$ \\
\hline USDA SD & 1.8 & $4.2 \mathrm{~Hz}$ & 35 DAFB & $62.1 \mathrm{~b}$ \\
\hline Control & \multicolumn{2}{|c|}{ Hand thinned } & 35 DAFB & $78.1 \mathrm{a}$ \\
\hline & & & \multicolumn{2}{|c|}{ 'PF17' Trial 2, 2009} \\
\hline USDA SD & 1.2 & $5.0 \mathrm{~Hz}$ & $60 \% \mathrm{FB}$ & $39.3 \mathrm{~b}$ \\
\hline USDA SD & 1.2 & $5.0 \mathrm{~Hz}$ & 35 DAFB & $31.9 \mathrm{~b}$ \\
\hline USDA SD & 1.2 & $5.0 \mathrm{~Hz}$ & $60 \% \mathrm{FB}$ & \\
\hline + USDA SD & 1.2 & $5.0 \mathrm{~Hz}$ & 35 DAFB & $33.1 \mathrm{~b}$ \\
\hline Control & \multicolumn{2}{|c|}{ Hand thinned } & 35 DAFB & $53.9 \mathrm{a}$ \\
\hline
\end{tabular}

${ }^{\mathrm{z}} \mathrm{DAFB}=$ days after full bloom.

${ }^{\mathrm{y}}$ Darwin is the Darwin 300 string thinner (Fruit-Tec, Deggenhausertal, Germany); USDA DD is the USDA double-spiked drum shaker that is a trailer-mounted unit designed to harvest citrus; Grower SD is a trailermounted grower-built single-drum unit patterned after the USDA DD unit but with one drum; USDA SD is a self-propelled prototype single-drum unit designed and built by the USDA. All trees trained to a perpendicular-V system with one main scaffold oriented on each side of the tree and perpendicular to a line running down the center of the tree row.

${ }^{\mathrm{x}}$ Forward speed is travel speed of the tractor or the self-propelled unit. Machine speed is the operating speed of the thinning machine in revolutions or Hertz. Growth stage is the stage of tree development or time in days after full bloom when treatment was applied.

${ }^{\mathrm{w}} \mathrm{FB}=$ full bloom

'Mean separation within columns, cultivars, and years by Fisher's protected least significant difference at $P \leq 0.05$. bining the Darwin string thinner at bloom and a drum shaker at 35 DAFB generally reduced follow-up hand-thinning time more than either mechanical device used alone. Using combinations of a mechanical thinner at blossom time followed by another mechanical thinning at the green fruit stage may provide a means to reduce hand-thinning labor while also reducing the risks of overthinning associated with attempting to achieve optimal crop load at a single timing, i.e., a "nibble" approach. In 2009 , only the USDA single-drum shaker at the $60 \%$ FB stage did not reduce the followup hand-thinning time compared with the hand-thinned control trees (Table 3). The USDA single-drum shaker was equally effective in reducing the follow-up handthinning time as the Darwin string thinner at $60 \% \mathrm{FB}$ in 2009.

Follow-up hand-thinning time appeared to be impacted by several factors that are not easily documented. Although the commercial thinners selected to thin the test plots were "experienced peach thinners," it was obvious that they were affected by the different conditions presented by the mechanically thinned trees, particularly those thinned by the drum shakers. In addition, some of the trees were quite tall (up to $5 \mathrm{~m}$ ) requiring the use of a stepladder, which slowed the thinning process.

Fruit size and yield. Resources did not permit fruit firmness measurements at harvest in this study. Fruit damage, bruising or marking, was not observed in any of the fruit harvested in this study and has not been observed or reported in previous tests with a string thinner or various mechanical drum shakers (Schupp et al., 2008).

Average fruit diameter was increased in 2008 with the Darwin string thinner plus the drum shaker (USDA or grower unit) or the USDA drum shaker used alone at $60 \%$ FB compared with the hand-thinned control (Table 4). Mechanical thinning treatments reduced both total yield and the yield of high market value size fruit in 'Sugar Giant' an average of $38 \%$ compared with the handthinned control. In 2009 on 'John Boy', the Darwin at $60 \% \mathrm{FB}$ and the combination treatment of USDA single-drum shaker at $60 \% \mathrm{FB}$ and at $35 \mathrm{DAFB}$ increased average fruit size and decreased total yield compared with the hand-thinned control, but only the USDA single-drum shaker alone at $60 \% \mathrm{FB}$ or combined with green fruit thinning at 35 DAFB increased the yield of high market value fruit $(7.0 \mathrm{~cm}$ or greater) (Table 4$)$. Trials with the USDA single-drum shaker on 'PF17' in 2009 demonstrated no increase in fruit diameter compared with the hand-thinned control. In both 'PF17' trials in 2009, total yield was reduced by all treatments with the USDA single-drum shaker, except when thinning green fruit (35 DAFB) and operating at $4.2 \mathrm{~Hz}$ and traveling at $1.2 \mathrm{~km} \cdot \mathrm{h}^{-1}$. In the 'PF17' Trial 2, the USDA single-drum shaker was tested at the $60 \% \mathrm{FB}$ stage and at 35 DAFB alone or in combination. Total yield was reduced by $17 \%$ by the single-drum shaker at the $60 \%$ FB stage, but yield was reduced by $67 \%$ when used at 35 DAFB and by $55 \%$ on 
Table 4. Peach fruit size, size distribution, and high market value yield as affected by a vertical string thinner, drum shakers, or a combination of these thinning treatments, 2008-2009. ${ }^{\mathrm{z}}$

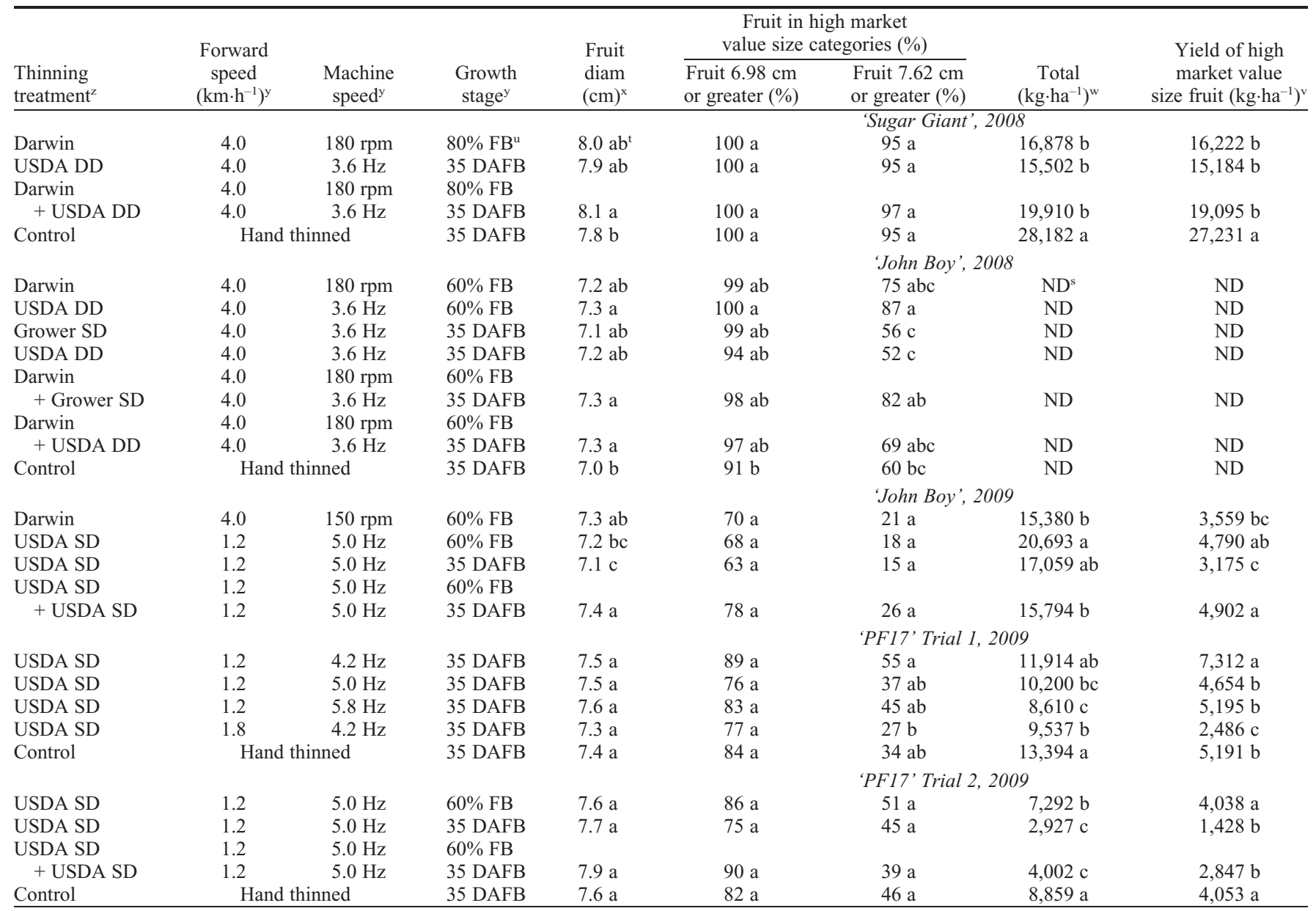

${ }^{2}$ Darwin is the Darwin 300 string thinner (Fruit-Tec, Deggenhausertal, Germany); USDA DD is the USDA double-spiked drum shaker that is a trailer-mounted unit designed to harvest citrus; Grower SD is a trailer-mounted grower built single-drum unit patterned after the USDA DD unit but with one drum; USDA SD is a self-propelled prototype single-drum unit designed and built by the USDA. All trees trained to a perpendicular-V system with one main scaffold oriented on each side of the tree and perpendicular to a line running down the center of the tree row.

${ }^{\mathrm{y}}$ Forward speed is travel speed of the tractor or the self-propelled unit. Machine speed is the operating speed of the thinning machine in revolutions or Hertz. Growth stage is the stage of tree development or time in days after full bloom when treatment was applied.

${ }^{x}$ Fruit diameter and packout distribution determined on 40 fruit harvested per treatment from each of six replicates.

"Yield calculated from fruit counts per scaffold (one of the two leaders on the perpendicular-V trained trees) and percent size distribution at harvest.

'High market value fruit are all fruit $7.62 \mathrm{~cm}$ or greater in diameter for 'Sugar Giant' and all fruit $6.98 \mathrm{~cm}$ or greater for 'John Boy' and 'PF17'.

"FB = full bloom.

'Mean separation within columns, cultivars, and years by Fisher's protected least significant difference at $P \leq 0.05$.

${ }^{\mathrm{s}} \mathrm{ND}=$ no data taken.

trees thinned both at $60 \% \mathrm{FB}$ and again at 35 DAFB (Table 3). Increasing the frequency of operation from 4.2 to 5.0 and then to $5.8 \mathrm{~Hz}$ with the USDA single-drum shaker at 35 DAFB resulted in further reduction in total yield. That most trials demonstrated little or no gain in the percent of fruit in the high market value size categories compared with the handthinned controls but experienced a significant drop in total yield suggests that the commercial thinning crews tended to overthin the mechanically thinned trees. Observations during the follow-up hand thinning in the field confirmed that the commercial growers' thinners generally overthinned the mechanically thinned trees. Additional training for thinning crews and oversight during the hand-thinning operation appear warranted. Workers should be trained to thin based on optimum crop load rather than fruit spacing and/or a specific number of fruit per node where mechanical thinning is used.
Previous studies have shown that drum shakers tend to remove the largest fruit when used at the green fruit stage (Glenn et al., 1994; Schupp et al., 2008). For large-fruited cultivars (e.g., Sugar Giant), this may not be a problem, but for smaller fruited cultivars, this may reduce the percentage of large fruit at harvest. However, this was not found in the current study because the percent of fruit 7.62 $\mathrm{cm}$ or greater in diameter on drum-thinned trees did not differ from that for hand-thinned trees. Selectively thinning to reduce or avoid thinning the largest fruit with a rod drum shaker design will be difficult, if not impossible. Fewer rods on each whorl of the drum may be an approach to affect this problem.

Thinning cost and economic impact. Mechanical thinning devices in all trials reduced the cost of follow-up hand thinning (Table 5). Average reduction in the follow-up handthinning cost ranged from $18 \%$ to $\approx 36 \%$. In the 2008 trials, the combination of the Darwin string thinner at bloom followed at 35 DAFB with the USDA double-drum shaker produced the greatest reduction $(\approx 43 \%)$ in the follow-up hand-thinning cost. Follow-up hand-thinning costs were reduced an average of $\approx 30 \%$ where the Darwin string thinner was used in these studies. The USDA double-drum shaker reduced follow-up hand-thinning cost by $\approx 24 \%$ when used at the $60 \%$ FB stage. The USDA single-drum unit produced similar savings when used at the bloom stage (Table 5). In all trials, combining a mechanical bloom thinning treatment with a green fruit stage thinning resulted in additional savings in follow-up hand-thinning cost over the individual devices used alone suggesting additional thinning had occurred when the mechanical methods were combined.

The net economic impact is dependent on a multitude of factors, including crop load, fruit size distribution, efficacy of the follow-up 


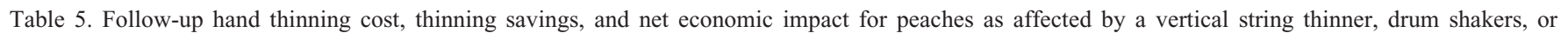
a combination of these thinning treatments, 2008-2009. ${ }^{\mathrm{z}}$

\begin{tabular}{|c|c|c|c|c|c|c|}
\hline $\begin{array}{l}\text { Thinning } \\
\text { treatment }^{\mathrm{z}}\end{array}$ & $\begin{array}{c}\text { Forward } \\
\text { speed }\left(\mathrm{km} \cdot \mathrm{h}^{-1}\right)^{\mathrm{y}}\end{array}$ & $\begin{array}{l}\text { Machine } \\
\text { speed }^{\mathrm{y}}\end{array}$ & $\begin{array}{l}\text { Growth } \\
\text { stage }^{\mathrm{y}}\end{array}$ & $\begin{array}{l}\text { Follow-up hand } \\
\text { thinning }(\$ / \text { ha })^{\mathrm{x}}\end{array}$ & $\begin{array}{c}\text { Thinning } \\
\text { savings }(\$ / h a)^{\mathrm{w}}\end{array}$ & $\begin{array}{l}\text { Net economic } \\
\text { impact }(\$ / \mathrm{ha})^{\mathrm{v}}\end{array}$ \\
\hline & & & & \multicolumn{3}{|c|}{ 'Sugar Giant', 2008, 944 trees/ha } \\
\hline Darwin & 4.0 & $180 \mathrm{rpm}$ & $80 \% \mathrm{FB}^{\mathrm{u}}$ & 506 & 244 & 203 \\
\hline USDA DD & 4.0 & $3.6 \mathrm{~Hz}$ & 35 DAFB & 738 & $(30)$ & $(84)$ \\
\hline Darwin & 4.0 & $180 \mathrm{rpm}$ & $80 \% \mathrm{FB}$ & & & \\
\hline + USDA DD & 4.0 & $3.6 \mathrm{~Hz}$ & 35 DAFB & 463 & 191 & 281 \\
\hline Control & \multicolumn{2}{|c|}{ Hand thinned } & 35 DAFB & 812 & - & - \\
\hline & & & & \multicolumn{3}{|c|}{ 'John Boy', 2008, 944 trees/ha } \\
\hline Darwin & 4.0 & $180 \mathrm{rpm}$ & $60 \% \mathrm{FB}$ & 445 & 48 & 1050 \\
\hline USDA DD & 4.0 & $3.6 \mathrm{~Hz}$ & $60 \% \mathrm{FB}$ & 419 & 56 & 1496 \\
\hline Grower SD & 4.0 & $3.6 \mathrm{~Hz}$ & 35 DAFB & 400 & 91 & 738 \\
\hline USDA DD & 4.0 & $3.6 \mathrm{~Hz}$ & 35 DAFB & 424 & 51 & (73) \\
\hline Darwin & 4.0 & $180 \mathrm{rpm}$ & $60 \% \mathrm{FB}$ & & & \\
\hline + Grower SD & 4.0 & $3.6 \mathrm{~Hz}$ & 35 DAFB & 366 & 57 & 1241 \\
\hline Darwin & 4.0 & $180 \mathrm{rpm}$ & $60 \% \mathrm{FB}$ & & & \\
\hline + USDA DD & 4.0 & $3.6 \mathrm{~Hz}$ & 35 DAFB & 318 & 94 & 888 \\
\hline Control & \multirow{2}{*}{\multicolumn{2}{|c|}{ Hand thinned }} & 35 DAFB & 556 & - & - \\
\hline & & & & \multicolumn{3}{|c|}{ 'John Boy', 2009, 944 trees/ha } \\
\hline Darwin & 4.0 & $150 \mathrm{rpm}$ & $60 \% \mathrm{FB}$ & 392 & 131 & 718 \\
\hline USDA SD & 1.2 & $5.0 \mathrm{~Hz}$ & $60 \% \mathrm{FB}$ & 476 & 47 & 570 \\
\hline USDA SD & 1.2 & $5.0 \mathrm{~Hz}$ & 35 DAFB & 434 & 89 & 365 \\
\hline USDA SD & 1.2 & $5.0 \mathrm{~Hz}$ & $60 \% \mathrm{FB}$ & & & \\
\hline + USDA SD & 1.2 & $5.0 \mathrm{~Hz}$ & $60 \% \mathrm{FB}$ & 432 & 90 & 763 \\
\hline Control & \multicolumn{2}{|c|}{ Hand thinned } & 35 DAFB & 590 & - & - \\
\hline & & & & \multicolumn{3}{|c|}{ 'PF17' Trial 1, 2009, 944 trees/ha } \\
\hline USDA SD & 1.2 & $4.2 \mathrm{~Hz}$ & 35 DAFB & 570 & $(34)$ & 487 \\
\hline USDA SD & 1.2 & $5.0 \mathrm{~Hz}$ & 35 DAFB & 563 & (27) & $(262)$ \\
\hline USDA SD & 1.2 & $5.8 \mathrm{~Hz}$ & 35 DAFB & 564 & (28) & $(12)$ \\
\hline USDA SD & 1.8 & $4.2 \mathrm{~Hz}$ & 35 DAFB & 563 & (7) & $(513)$ \\
\hline Control & \multicolumn{2}{|c|}{ Hand thinned } & 35 DAFB & 684 & - & - \\
\hline & & & & \multicolumn{3}{|c|}{ 'PF17' Trial 21, 2009, 944 trees/ha } \\
\hline USDA SD & 1.2 & $5.0 \mathrm{~Hz}$ & $60 \% \mathrm{FB}$ & 344 & 58 & 580 \\
\hline USDA SD & 1.2 & $5.0 \mathrm{~Hz}$ & 35 DAFB & 279 & 123 & $(170)$ \\
\hline USDA SD & 1.2 & $5.0 \mathrm{~Hz}$ & 35 DAFB & & & \\
\hline + USDA SD & 1.2 & $5.0 \mathrm{~Hz}$ & $60 \% \mathrm{FB}$ & 289 & 112 & 1012 \\
\hline Control & \multicolumn{2}{|c|}{ Hand thinned } & 35 DAFB & 471 & - & - \\
\hline
\end{tabular}

${ }^{\mathrm{z}}$ Darwin is the Darwin 300 string thinner (Fruit-Tec, Deggenhausertal, Germany); USDA DD is the USDA double-spiked drum shaker that is a trailer-mounted unit designed to harvest citrus; Grower SD is a trailer-mounted grower-built single-drum unit patterned after the USDA DD unit but with one drum; USDA SD is a self-propelled prototype single-drum unit designed and built by the USDA. All trees trained to a perpendicular-V system with one main scaffold oriented on each side of the tree and perpendicular to a line running down the center of the tree row.

${ }^{\mathrm{y}}$ Forward speed is travel speed of the tractor or the self-propelled unit. Machine speed is the operating speed of the thinning machine in revolutions or Hertz. Growth stage is the stage of tree development or time in days after full bloom when treatment was applied.

${ }^{x}$ Follow-up hand thinning cost is based on a labor rate of $\$ 8.50 / \mathrm{h}$ in 2008 and $\$ 8.75$ in 2009 .

wThinning savings includes reduced follow-up hand thinning inputs and added mechanical thinner, tractor, and labor inputs. Mechanical thinner cost is based on a 15 -year useful life of equipment and $8 \%$ interest rate. Tractor cost is $\$ 12.00 / \mathrm{h}$; equipment operator cost is $\$ 12.00 / \mathrm{h}$.

${ }^{\mathrm{N}}$ Net economic impact (realized economic savings) is defined as cost/benefit beyond hand thinning alone and takes into account reduced hand-thinning inputs and increased value of fruit in higher size categories.

${ }^{\mathrm{u} F B}=$ full bloom; DAFB = days after full bloom.

hand thinners in removing additional unwanted fruits, and machine operating costs. In general, the combined use of a mechanical device (string or drum shaker) at bloom and at the green fruit stage (drum shaker at $\approx 35$ DAFB) produced the greatest positive economic impact (realized economic savings beyond hand thinning alone) (Table 5). The Darwin string thinner, designed to bloom thin, consistently produced a positive economic impact, a finding supported by a previous study (Baugher et al., 2009). The drum shaker (double- or single-drum model) was intended to thin green fruit but performed quite well at the $60 \% \mathrm{FB}$ stage and showed a positive economic impact in all three trials in which it was used to thin bloom. In the trials between 2008 and 2009, the greatest economic impact $(\$ 1496 / \mathrm{ha})$ was a result of the USDA double-drum shaker used to thin 'John Boy' at the $60 \%$ FB stage (Table 5).

Leafllimb damage. No leaf damage was observed in any of the trials described here.
Unlike in apple, at the time of bloom, peach leaf tissue is not sufficiently exposed to warrant damage from a string thinner or the drum shakers. In 5 years of testing various drum shakers (Schupp et al., 2008, and current report), no damage has been observed where the drum shaker devices have been used at the green fruit stage.

'John Boy' and 'Sugar Giant' treatment trees were examined soon after thinning for areas on the main scaffold limb where the bark had been broken and/or removed by the mechanical thinning devices (Table 6). In addition, the number of 1-year-old shoots or older branches broken during the thinning operation was recorded per tree. The Darwin string thinner produced no broken bark but did result in a limited number of broken branches in the 'Sugar Giant' trees, but not more than the hand-thinned control trees (Table 6). Both the USDA double-drum shaker and the grower single-drum shaker produced significantly more bark damage than the Darwin string thinner or the hand-thinned control in the 'John Boy' peach trees. Bark damage from the grower single-drum shaker was significantly less than from the two USDA double-drum shaker treatments. In the 'John Boy' trial, the USDA double-drum shaker at the $60 \%$ FB stage resulted in the most barkdamaged area among all treatments. There was no difference in the number of branches broken by the mechanical thinning treatments in 'John Boy'. In the 'Sugar Giant' trials, the USDA double-drum shaker at 35 DAFB produced the greatest amount of bark damage and the largest number of broken branches.

Bark damage and broken limbs have been a concern with the drum shaker unit (Schupp et al., 2008). The drum shaker used in the 2008 trials was the original two-drum unit designed to harvest citrus. This unit is a large trailer-mounted unit that can be difficult to maneuver down the row and has large, fairly 
Table 6. Damage to scaffold limbs and branches on 'Sugar Giant' and 'John Boy' peach trees after mechanical thinning with a Darwin string thinner, two models of drum shakers, or a combination of the two types of mechanical thinners in $2008 .^{\mathrm{z}}$

\begin{tabular}{|c|c|c|c|c|c|}
\hline $\begin{array}{l}\text { Thinning } \\
\text { treatment }^{\mathrm{z}}\end{array}$ & $\begin{array}{l}\text { Forward } \\
\text { speed } \\
\left(\mathrm{km} \cdot \mathrm{h}^{-1}\right)^{\mathrm{y}}\end{array}$ & $\begin{array}{l}\text { Machine } \\
\text { speed }^{\mathrm{y}}\end{array}$ & $\begin{array}{l}\text { Growth } \\
\text { stage }^{y}\end{array}$ & $\begin{array}{l}\text { Area injured } \\
\text { on main } \\
\text { scaffold }\left(\mathrm{cm}^{2}\right)^{x}\end{array}$ & $\begin{array}{c}\text { Broken } \\
\text { branches } \\
\text { (number/tree) }\end{array}$ \\
\hline & & & & \multicolumn{2}{|c|}{ 'Sugar Giant' } \\
\hline USDA DD & 4.0 & $3.6 \mathrm{~Hz}$ & $35 \mathrm{DAFB}^{\mathrm{v}}$ & $28.7 \mathrm{a}^{\mathrm{u}}$ & $2.0 \mathrm{a}$ \\
\hline Drawin & 4.0 & $180 \mathrm{rmp}$ & $80 \% \mathrm{FB}$ & $0.0 \mathrm{bc}$ & $0.4 \mathrm{c}$ \\
\hline Drawin & 4.0 & $180 \mathrm{rmp}$ & $80 \% \mathrm{FB}$ & & \\
\hline + USDA DD & 4.0 & $3.6 \mathrm{~Hz}$ & 35 DAFB & $16.9 \mathrm{ab}$ & $1.2 \mathrm{~b}$ \\
\hline Control & \multicolumn{2}{|c|}{ Hand thinned } & 35 DAFB & $0.0 \mathrm{c}$ & $0.0 \mathrm{c}$ \\
\hline & & & & \multicolumn{2}{|c|}{ 'John Boy' } \\
\hline USDA DD & 4.0 & $3.6 \mathrm{~Hz}$ & $60 \% \mathrm{FB}$ & $18.9 \mathrm{a}$ & $0.2 \mathrm{a}$ \\
\hline USDA DD & 4.0 & $3.6 \mathrm{~Hz}$ & 35 DAFB & $8.7 \mathrm{~b}$ & $0.1 \mathrm{a}$ \\
\hline Grower SD & 4.0 & $3.6 \mathrm{~Hz}$ & 35 DAFB & $4.4 \mathrm{c}$ & $0.2 \mathrm{a}$ \\
\hline Drawin & 4.0 & $180 \mathrm{rmp}$ & $60 \% \mathrm{FB}$ & $0.0 \mathrm{~d}$ & $0.0 \mathrm{a}$ \\
\hline Control & \multicolumn{2}{|c|}{ Hand thinned } & 35 DAFB & $0.0 \mathrm{~d}$ & $0.0 \mathrm{a}$ \\
\hline
\end{tabular}

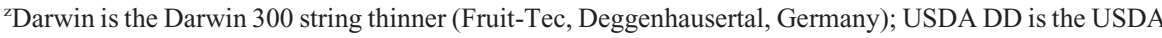
double-spiked drum shaker that is a trailer-mounted unit designed to harvest citrus; Grower SD is a trailermounted grower-built single-drum unit patterned after the USDA DD unit but with one drum; USDA SD is a self-propelled prototype single-drum unit designed and built by the USDA. All trees trained to a perpendicular-V system with one main scaffold oriented on each side of the tree and perpendicular to a line running down the center of the tree row.

${ }^{y}$ Forward speed is travel speed of the tractor or the self-propelled unit. Machine speed is the operating speed of the thinning machine in revolutions or Hertz. Growth stage is the stage of tree development or time in days after full bloom when treatment was applied.

${ }^{x}$ Mean total of injured area.

wIncludes 1-year-old branches or older.

${ }^{\mathrm{v}} \mathrm{FB}=$ full bloom; DAFB $=$ days after full bloom.

"Mean separation within columns, cultivars, and years by Fisher's protected least significant difference at $P \leq 0.05$

stiff nylon rods that can become lodged in the crotch area of narrow branches. As the unit proceeds down the row, the rods are ejected from these narrow crotches with enough force to break the bark. It has also been observed that if the rounded end of a rod strikes squarely on a stiff branch, the bark will often be broken. Two drums increase the likelihood of damage, as evidenced by the lower amount of bark damage with the grower single-drum unit. A self-propelled single-drum unit designed to operate without a counterbalance spindle should be examined as a way to reduce bark damage and limb breakage.

\section{Conclusions}

Our current results demonstrate the effectiveness of a Darwin mechanical string thinner or a single- or double-spiked drum shaker for thinning peaches on perpendicular- $\mathrm{V}$ trained trees. In our opinion, these mechanical devices could also effectively thin trees trained to other systems with narrow canopies such as pillar or slender spindle form trees. The drum shaker units are not designed for large conventional open-center vase-formed trees, but may be effective in high-density quadrilateral$\mathrm{V}$ planting systems. The Darwin string thinner has been modified to adapt to open-center trees (Baugher et al., 2009).

Our results support earlier findings (Baugher et al., 2009, 2010; Schupp et al., 2008) and demonstrate that additional benefits in economic impact through larger fruit and/or reduced follow-up hand-thinning times may be realized by combining bloom thinning with green fruit thinning. Although mechanical thinners can clearly reduce crop loads and the time required for follow-up hand thinning in peach, the current state of the art does not replace the need for hand thinning. It should also be pointed out that the mechanical devices described here are not capable of selective thinning in the sense they can target a specific bloom or fruit. Shakers, by design and mode of operation, tend to remove larger sized fruits than smaller fruit. This may have a negative impact on the yield of large-sized fruit at harvest. However, the saving in labor and time may offset the small increase in returns gained by a few larger fruit at harvest. Our results suggest that, like many modern intensive orchard practices, the use of mechanical devices for thinning requires attention to detail in timing, operation of the equipment, training systems used, and cultivar differences to achieve optimum results. Follow-up hand thinning may require a different set of heuristics where mechanical thinning is practiced (e.g., fruit spacing) than normally applied to traditional hand thinning in peach. As most tree fruit growers know, there is an inherent risk in bloom thinning where late-season frost/ freeze events occur. In these areas, growers would be cautioned to use the minimal mechanical bloom thinning techniques and use green fruit thinning as a supplement after the threat of frost has passed. Additional field studies are warranted, especially with the mechanical drum shakers, to achieve a more economical, reliable, and realistic level of thinning and final crop load.

\section{Literature Cited}

Baugher, T.A., K.C. Elliott, D.W. Leach, B.D. Horton, and S.S. Miller. 1991. Improved methods of mechanically thinning peaches at full bloom. J. Amer. Soc. Hort. Sci. 116:766-769.

Baugher, T.A., J. Schupp, K. Ellis, J. Remcheck, E. Winzeler, R. Duncan, S. Johnson, K. Lewis, G. Reighard, G. Henderson, M. Norton, A. Dhaddey, and P. Heinemann. 2010. String blossom thinner designed for variable tree forms increases crop load management efficiency in trials in four United States peach-growing regions. HortTechnology 20:409-414.

Baugher, T.A., J.R. Schupp, K.M. Lesser, and K. Hess-Reichard. 2009. Horizontal string blossom thinner reduces labor input and increases fruit size in peach trees trained to open-center systems. HortTechnology 19:755-761.

Berlage, A.G. and R.D. Langmo. 1982. Machine vs. hand thinning of peaches. Trans. Amer. Soc. Agr. Eng. 25:538-543.

Byers, R.E. 1989. Response of peach trees to bloom thinning. Acta Hort. 254:125-132.

Byers, R.E. 1990. Thin peaches with water. Amer. Fruit Grower 110(1):20-21.

Byers, R.E., G. Costa, and G. Vizzotto. 2003. Flower and fruit thinning of peach and other Prunus. Hort. Rev. (Amer. Soc. Hort. Sci.) 28:351-391.

Damerow, L. and M.M. Blanke. 2009. A novel device for precise and selective thinning in fruit crops to improve fruit quality. Acta Hort. 824:275-280.

Glenn, D.M., D.L. Peterson, D. Giovannini, and M. Faust. 1994. Mechanical thinning of peaches is effective postbloom. HortScience 29:850-853.

Harper, J.K., R.M. Crassweller, and D.E. Smith. 2002. Impact of apple rootstock/cultivar on processing market profitability. J. Amer. Pomological Soc. 56:112-117.

Havis, L. 1962. Effects of time of fruit thinning of Redhaven peach. Proc. Amer. Soc. Hort. Sci. 80: 172-176.

Marini, R.P. and D.L. Sowers. 1990. Net photosynthesis, specific leaf weight, and flowering of peach as influenced by shade. HortScience 25:331-334.

Miller, S. and T. Tworkoski. 2010. Blossom thinning in apple and peach with an essential oil. HortScience 45:1218-1225.

Peterson, D.L. 1998. Mechanical harvester for process oranges. Appl. Eng. Agr. 14:455-458.

Powell, A.A., B.G. Hancock, E.E. Puls, Jr., S.G. Helmers, and M.H. Brown, Jr. 1975. Utilizing mechanical fruit thinning in commercial peach orchards. HortScience 10:142 (abstr.).

Rosa, U.A., K.G. Cheetancheri, C.J. Gliever, S.H. Lee, J. Thompson, and D.C. Slaughter. 2008. An electro-mechanical limb shaker for fruit thinning. Comput. Electron. Agr. 61:213-221.

Schupp, J.R., T.A. Baugher, S.S. Miller, R.M. Harsh, and K.M. Lesser. 2008. Mechanical thinning of peach and apple trees reduces labor input and increases fruit size. HortTechnology 18:660-670.

Tukey, H.B. and O. Einset. 1938. Effect of fruit thinning on size, color, and yield of peaches and on growth and blossoming of the tree. Proc. Amer. Soc. Hort. Sci. 36:314-319.

U.S. Department of Agriculture. 2009. USDA agricultural marketing service report. USDA fruit and vegetable news. 10 Dec. 2009. http:// marketnews.usda.gov/portal/fv?paf_dm=full \&paf_gear_id $=1200002 \&$ startIndex $=1 \& \mathrm{dr}=$ $1 \&$ rowDisplayMax $=25 \&$ repType=termPriceDaily $\& d r=1 \&$ locName $=\&$ commAbr $=$ PCH\&comm Name $=$ PEACHES.

Warner, G. 2009. Stone fruit thinning. Good Fruit Grower 60:18. 